\title{
Effects of Work-Life Balance Policies on Female Commitment towards the Same Company
}

\author{
Mamiko Takeuchi ${ }^{1}$ \\ ${ }^{1}$ Office for the Promotion of Gender Equality, Kyushu University, Japan \\ Correspondence: Mamiko Takeuchi, Associate Professor, Office for the Promotion of Gender Equality, Kyushu \\ University, Japan.
}

Received: October 6, 2017

Accepted: October 23, 2017

Online Published: November 24, 2017

doi:10.5430/ijba.v8n7p139

URL: https://doi.org/10.5430/ijba.v8n7p139

\begin{abstract}
This paper explores the relationship between work-life balance (WLB) policies and three indicators-job tenure, turnover rates, and new graduate retention rates in Japan-focusing on the careers of female employees. Cross-sectional analysis shows that firms with WLB policies, such as a full amount of maternity pay, are positively associated with female employee job tenure. Additionally, panel data analysis shows that the practices of family-care leave, family-care benefits, and flextime system, have an effect on the turnover rate of female employees. Moreover, the full amount of maternity pay has an effect on the retention rate of female new graduates. Finally, a first-differences analysis also finds a positive relationship between the maternity pay system and female job tenure. These results suggest that WLB policies, such as the full amount of maternity pay, family-care leave, family-care benefits, and flextime system, could produce positive outcomes for the careers of female employees.
\end{abstract}

Keywords: panel data analysis, female careers, work-life balance policy

\section{Introduction}

In Japan, the Act on the Promotion of Women's Active Participation in Their Occupational Lives (Promotion of Women's Activities Law) came into effect on April 1, 2016. To realize a society where all women who wish to play an active role in the workplace can fully demonstrate their individuality and abilities, employers (national and local public entities, private enterprises, etc.) were obliged to formulate and announce action plans incorporating numerical targets for promoting successful female employees and publish information on work-life balance (WLB), thus contributing to women's job selection. Promoting women's success is not just a Japanese trend, but a global one. For example, the Asia-Pacific Economic Cooperation often holds high-level meetings on the theme of women and the economy. The member countries share the recognition that women are active in enhancing society sustainability and becoming a driving force of economic growth. However, even in the European Union, the potential of women is not fully utilized in economic activities. Recognizing this as a loss, not only for women themselves, but also for the wider economy, various efforts are being made to encourage women's participation in the economy in association with "Europe 2020," which is a 10-year growth strategy started in 2010 (Gender Equality White Paper, 2013).

Although the female employment rate in Japan has risen sharply recently, the number of women in managerial roles is lower than in Western countries. As such, it cannot be said that women's strengths in the workplace have been sufficiently demonstrated. Thus, it is important for the society as a whole to strive so that women who wish to work can do so in a manner that satisfies their requirements. Further, amid concerns about a future labor shortage, as the population continues to age due to low birthrates, companies must increase profitability and productivity to sustain Japan's development. Therefore, it is urgently necessary to further the participation of women as soon as possible and demonstrate, to the highest degree, their capabilities (Gender Equality White Paper, 2017).

Efforts aimed at realizing WLB in the era of population decline can be said to enhance the possibility of securing, nurturing, and establishing talented personnel, which is a source of corporate vitality and competitiveness. According to the "Work-Life Balance Charter," formulated in Japan in 2007, these efforts should be viewed as an "investment for tomorrow," not as a "cost" for companies. While companies and their employees cooperate to increase productivity, they are also obliged to voluntarily strive to reform their way of working, as well as their workplace awareness and culture. 
The Law on Child Care and Family Care Leave has been playing a central role in promoting family-friendly policies since 1992. It stipulates that employees can take a leave until their infants become one-year old. The government promotes the concept of a childcare leave system, with the aim of raising the fertility rate and allowing female employees to continue working after childbirth. Moreover, The Law on Child Care and Family Care Leave was revised in 2005. According to this revision, employees who meet certain conditions can avail child-rearing leave until their children reach the age of one year and a half, and can also take one family care leave for one family member in need of constant care for a maximum of 93 days. Along with such social movements, companies that pay attention to employees' WLB have increased.

Given this social background, this paper examines the various WLB policies that affect female careers, in terms of new graduate retention rates, job tenure, and turnover rates in Japan. These three indicators are important for the accumulation of human resources in a company. New graduate retention rates indicate whether companies conduct enough job training for young employees, where longer job tenure promotes employees to managerial positions and smaller turnover rates indicate better working conditions, especially for women employees after marriage and childbirth.

This paper is organized as follows: the subsequent section introduces preceding studies about WLB and female careers; the third section describes the estimation method; the fourth section presents the data and descriptive statistics; the fifth section introduces the analytical results; and the sixth section concludes this study.

\section{Literature Review}

Youngblood and Chambers-Cook (1984), and Kossek and Nichol (1992) find that childcare benefits are more likely to positively influence employee attitudes and membership behaviors, such as recruitment and retention. Furthermore, Batt and Valcour (2003) suggest that the most effective organizational responses to work-family conflicts and turnover are those that combine work-family policies with other human resources practices, including work redesign and commitment-enhancing incentives.

More recently, Baker and Milligan (2008) find that job-protecting maternity leaves can increase the time female employees spend at home with their infants and the probability of returning to their pre-birth employer. They also find that the increase in job continuity associated with longer leaves comes from two sources: some female employees come back to the workforce instead of permanently quitting to take care of their child; another large share of mothers switch from taking new, mostly part-time jobs, while their child is young to taking longer leaves before returning to the pre-birth employer fulltime.

Additionally, Dalton and Mesch (1990) compare the absenteeism and turnover of employees in two divisions of one company: one with and one without flexible-scheduling programs. The results indicate gross reductions in absenteeism for employees who used the flexible system, while turnover was not affected. Moreover, Thomas and Ganster (1995) find that employees who use flextime have more control over managing work and family demands, and also have a higher job satisfaction. Grover and Crooker (1995) show that family-responsive policies induce greater organizational loyalty and lower the intention of employees to quit their jobs. Additionally, childcare information referral has a greater impact on affective commitment among employees eligible for this benefit. Eaton (2003) also finds that flexible WLB policies have a positive association with organizational commitment and self-reported productivity.

WLB policies are also reported to have higher perceived firm-level performance (Perry Smith \& Blum, 2000), and have a stronger positive impact on productivity when women comprise a larger percentage of the workforce and a higher percentage of professionals is employed (Konrad \& Mangel, 2000).

In Japan, Shigeno and Ōkusa (1998) point out that, although the childcare leave system cannot influence women's marriage decisions, it is effective in facilitating continuous employment. Moreover, Imada and Ikeda (2006) observe that a majority of younger women quit their jobs during pregnancy, and Morita and Kaneko (1998) reveal that using the childcare leave system can increase the job tenure of female employees. Hence, supporting job continuity for female employees is important from the time of pregnancy, and the childcare leave system affects female employee retention. Consequently, support from family and relatives or usage of childcare centers are necessary.

However, it is important to note that companies are less willing to introduce WLB programs, unless these programs help generate profits. Furthermore, Matsubara and Wakisaka (2005) point out that WLB policies have often been considered a form of corporate welfare system that facilitates working female's constant career development. Recently, companies have been approaching these measures as part of substantial strategies for a better human resource management amidst trends such as declining birthrates and a rapid increase in aging. Greenwald (1996) 
argues that, although many corporate managers typically initiate WLB measures with the aim of improving employee amenities, such initiatives can definitely yield profit in the long run. Furthermore, Perry-Smith and Blum (2000) also note that WLB measures can have a positive impact on corporate performance from the perspective of competitive advantage.

Specifically, WLB policies are generally considered effective for boosting employee morale and improving working conditions. Based on data from corporate surveys and the employees involved in these companies, Sakazume (2002) demonstrates that WLB systems have a positive effect on boosting employee morale and improve working conditions.

Shigeno (2005) shows that, although WLB policies do not directly affect corporate performance, they lead to active utilization measures for female employees, which eventually have an indirect positive impact on corporate performance.

Moreover, Kodama, Odaki, and Takahashi (2005) reveal positive correlations between the percentage of female employees and corporate profitability and that intrinsic corporate factors, including personnel and general administrative management measures, can boost business performance and, eventually, the percentage of female employees.

According to main studies on Japan, the benefits of WLB programs are greater for companies in terms of securing the necessary labor force (Takeishi, 2006), lower turnover rate or higher retention rate of female employees (Sakazume, 2002), higher financial performance (Abe, 2008; Wakisaka, 2006). Kawaguchi (2002) notes the synergism between gender equality and family-friendly measures, arguing that the promotion of gender equality increases the necessity of implementing family-friendly measures and initiatives that can simultaneously drive gender equality.

In summary, prior studies on Japan have examined some outcomes associated with WLB policies, but have only examined isolated practices or the total performance index. Therefore, this paper examines the outcomes of various WLB policies.

Moreover, because most prior studies rely on cross-sectional data, they could not control for unobserved firm-specific effects. We control for firm-specific effects using panel datasets. Consequently, our main hypothesis is that corporate WLB policies are effective towards longer female employee job tenure, lower female employee turnover rates, and create higher retention rates for female new graduates.

\section{Data and Statistical Summary}

\subsection{Data}

This study uses a panel dataset from the 2000 to 2009 editions of the Quarterly Female Employment Report for analysis. The survey was conducted from 1998 to 2007, and offers a total sample size of 1,999 companies. It is an annual publication, based on a mail-in survey, and includes statistical information on female employees and human resource management practices such as WLB in listed Japanese companies. Additionally, the Report contains information on a wide range of workplace characteristics. This allows to control for organization size, industry type, and other characteristics to assess if having specific WLB policies are associated with a higher turnover intention for female employees.

As we focus on the effects of WLB practices in Japanese organizations, Table 1 shows the major WLB practices for the 2000-2009 editions of the Quarterly Female Employment Report. This table also shows the percentage of WLB policies adopted in Japanese organizations. Because the maternity and childcare leave systems are compulsory under the Labor Standards Law, they are adopted by most organizations. Although a portion of maternity benefits is required during maternity leave, according to the Health Insurance Law, the rates of adoption of the full amount of maternity pay are around $20 \%$ over the analyzed years. 
Table 1. Percentage of companies implementing work-life balance policies

\begin{tabular}{lccccccccccc}
\hline & \multicolumn{10}{c}{ year } \\
& 2000 & 2001 & 2002 & 2003 & 2004 & 2005 & 2006 & 2007 & 2008 & 2009 \\
\hline Work-life Balance Policies (\%) & & & & & & & & & & \\
Maternity leave system & 99.91 & 98.64 & 98.56 & 98.75 & 99.95 & 99.25 & 99.87 & 99.98 & 99.97 & 99.92 \\
Full amount of maternity pay & 27.22 & 25.56 & 27.22 & 24.85 & 25.28 & 20.11 & 26.38 & 27.21 & 22.55 & 25.98 \\
Childcare leave system & 100 & & & 98.87 & 99.42 & 99.4 & 98.77 & 98.63 & 100 & 98.42 \\
Childcare leave benefit & 1.04 & & & & & & & & & \\
Family-care leave system & 51.3 & & & & & & & & & \\
Family-care leave benefit & 3.66 & & & & & & & & & \\
Flextime system & 44.02 & & & & & & & & & & \\
Reemployment system & & 33.63 & 34.03 & & & & & & & & \\
\hline
\end{tabular}

Note: Blank spaces indicate the data are not available.

The 2000, 2001, and 2002 editions of the survey identify whether specific practices are conducted in each company: maternity leave system within the statutory period (six weeks before through eight weeks after childbirth), full amount of maternity pay, childcare leave system within the statutory period (children under the age of one), childcare leave benefits, family-care leave system (a total of 93 days), family-care leave benefits, flextime system, and reemployment system. The 2003 to 2009 editions of the Report listed only WLB practices, including maternity leave system within the statutory period, full amount of maternity pay, and childcare leave system within the statutory period.

We can see that the adoption of the childcare leave benefits, family-care leave benefits, and flextime system are also low in 2000. Particularly, only $1 \%$ of organizations offered the full amount of childcare leave benefits and $44 \%$ adopted the flextime system. Therefore, analyzing the effects of these WLB policies is highly significant.

\subsection{Descriptive Statistics}

The descriptive statistics for the variables used in the analysis are presented in Table 2, namely the means and standard deviations for the 2000 and 2000-2009 survey editions. Our analysis focuses on three different types of dependent variables in the first set of variables in this table. For the explanatory variables, the second set of variables represents various WLB policies, and the next set firm characteristics. From Table 2, we can confirm that mean job tenure for female employees is $9.09 \%$ shorter than for male employees. Additionally, the average turnover rate for female employees is $5.33 \%$ and the average retention rate for female new graduates $78.91 \%$.

Table 2. Descriptive statistics

\begin{tabular}{lcccc}
\hline & \multicolumn{3}{c}{ Years of Publication } \\
& \multicolumn{2}{c}{ 2000 } & \multicolumn{2}{c}{ 2000-2009 } \\
\hline Variable & Mean & Std. Dev. & Mean & Std. Dev. \\
\hline Turnover Intention & & & & \\
Female job tenure (year) & 9.098 & 3.433 & 10.123 & 4.193 \\
(Male job tenure) & 15.811 & 4.657 & 15.513 & 5.335 \\
Tenure gap & 6.712 & 3.366 & 5.387 & 3.123 \\
Female turnover rate & & & 5.335 & 5.672 \\
Female retention rate & & & 19.942 & 21.632 \\
WLB Policies (dummies) & & & & \\
Maternity leave & & & 0.991 & 0.033 \\
Maternity pay & 0.263 & 0.442 & 0.243 & 0.448 \\
Childcare leave & & & 0.993 & 0.073 \\
Childcare benefit & 0.067 & 0.252 & 0.150 & 0.216
\end{tabular}




\begin{tabular}{|c|c|c|c|c|}
\hline Family-care leave & 0.751 & 0.433 & 0.544 & 0.500 \\
\hline Family-care benefit & 0.090 & 0.287 & 0.038 & 0.305 \\
\hline Flextime system & 0.443 & 0.498 & 0.333 & 0.457 \\
\hline Reemployment system & 0.360 & 0.482 & 0.345 & 0.203 \\
\hline \multicolumn{5}{|l|}{ Other Characteristics } \\
\hline Labor union & 0.894 & 0.308 & 0.783 & 0.411 \\
\hline Monthly average overtime work (hour) & 18.204 & 9.566 & 18.235 & 9.312 \\
\hline Commuting allowance & 0.789 & 0.409 & 0.755 & 0.430 \\
\hline Qualification allowance & 0.383 & 0.488 & 0.479 & 0.499 \\
\hline Initial salary $(\log )$ per month & 12.210 & 0.053 & 12.225 & 0.058 \\
\hline Proportion of married women & & & 0.294 & 0.150 \\
\hline Proportion of female managers & & & 0.037 & 0.294 \\
\hline \multicolumn{5}{|l|}{ Organization Size } \\
\hline Number of male employees $(\log )$ & 7.710 & 1.019 & 7.305 & 0.837 \\
\hline \multicolumn{5}{|l|}{ Industry (dummies) } \\
\hline Construction & 0.037 & 0.021 & 0.037 & 0.031 \\
\hline Manufacturing & 0.545 & 0.031 & 0.465 & 0.040 \\
\hline Electricity & 0.022 & 0.001 & 0.006 & 0.001 \\
\hline Telecommunication & 0.059 & 0.002 & 0.092 & 0.002 \\
\hline Traffic & 0.029 & 0.001 & 0.029 & 0.001 \\
\hline Retailing & 0.194 & 0.050 & 0.214 & 0.089 \\
\hline Finance & 0.074 & 0.006 & 0.072 & 0.010 \\
\hline Lodging & 0.007 & 0.008 & 0.017 & 0.012 \\
\hline Entertainment & 0.007 & 0.005 & 0.008 & 0.001 \\
\hline Composed Service & 0.014 & 0.004 & 0.031 & 0.005 \\
\hline Other Services & 0.007 & 0.002 & 0.016 & 0.003 \\
\hline Farming & 0.000 & 0.000 & 0.007 & 0.002 \\
\hline Realty & 0.000 & 0.000 & 0.001 & 0.000 \\
\hline Specialized Service & 0.000 & 0.000 & 0.001 & 0.000 \\
\hline Education & 0.000 & 0.000 & 0.001 & 0.000 \\
\hline
\end{tabular}

Note: Missing values indicate the variables are not used for OLS estimation.

\section{Estimation Method}

\subsection{Model}

This study tests our hypothesis by estimating ordinary least squares (OLS), random effects, and first-differences models.

4.1.1 Ordinary Least Squares

$$
y_{i}=X_{i} \beta_{1}^{\prime}+Z_{i} \beta_{2}^{\prime}+\alpha+\varepsilon_{i}, \quad(i=1, \cdots, \mathrm{N}),
$$

where $E\left(\varepsilon_{i t}\right)=0, \operatorname{Var}\left(\varepsilon_{i}\right)=E\left(\varepsilon_{i}^{2}\right)=\sigma^{2}, i$ is the firm, and $t$ the time. $y_{i}$ is a dependent variable on the job tenure of female employees, $\alpha$ a constant term, and $X_{i}$ represents a set of regressors included as firm characteristics. $Z$ represents a set of regressors that shows the variety of WLB policies in each company. The OLS assumption is that $\varepsilon_{i}$ is white noise. We estimate OLS using cross-sectional data from the 2000 edition to test our hypothesis. 


\subsubsection{Random Effects Model}

$$
y_{i t}=X_{i t} \beta_{1}^{\prime}+Z_{i t} \beta_{2}^{\prime}+\alpha_{i}+\varepsilon_{i t}, \quad(i=1, \cdots, \mathrm{N} ; \mathrm{t}=1, \cdots \mathrm{T})
$$

where $E\left(\varepsilon_{i t}\right)=0, E\left(\alpha_{i}^{2}\right)=\sigma_{\alpha}^{2}, E\left(\alpha_{i} \varepsilon_{i t}\right)=0$ and $E\left(\alpha_{i} \mid X\right)=0 . \alpha_{i}$ represents stochastic independent terms and the random effects model assume that $\alpha_{i}$ is uncorrelated with the independent variables. To test our hypothesis, we use the random effects linear model, with average tenure and turnover rate as the dependent variables, and the random effects probit model, with retention rate for female new graduates as the dependent variables the. The probit model is a binary choice model. The reason for adopting this model is explained in the next section. We use panel data from the 2000 to 2009 editions to estimate this model.

\subsubsection{First-Differences Model}

$$
\Delta y_{i t}=\Delta X_{i t} \beta_{1}^{\prime}+\Delta Z_{i t} \beta_{2}^{\prime}+\Delta \varepsilon_{i t}, \quad(i=1, \cdots, \mathrm{N} ; \mathrm{t}=2, \cdots \mathrm{T})
$$

where $\Delta y_{i t}=\Delta y_{i t}-\Delta y_{i, t-1}, \Delta X_{i t}=\Delta X_{i t}-\Delta X_{i, t-1}, \Delta Z_{i t}=\Delta Z_{i t}-\Delta Z_{i, t-1} \Delta \varepsilon_{i t}=\Delta \varepsilon_{i t}-\Delta \varepsilon_{i, t-1}$. In this model, the $\alpha_{i}$ in (2) are assumed to represent the unobserved heterogeneity term, which is firm-specific and time-invariant. However, they are deleted by the first difference and model (3) is estimated using OLS. In other words, first-differences analysis can delete time-constant unobserved heterogeneity $\alpha_{i}$. Therefore, we can calculate the differences in the data between the 2000 and 2003, 2000 and 2006, 2000 and 2009 editions.

\subsection{Variables}

\subsubsection{Dependent Variables}

To analyze the effects of WLB policies, we use three measures for the dependent variables: job tenure and turnover rate for female employees, and retention rate for female new graduates who had stayed with their first company for three years. The turnover rate is replaced with $\log (\mathrm{p} /(1-\mathrm{p}))$ by a $\log$ odds ratio. Figure 1 shows the distributions of these three dependent variables. Obviously, the distributions of the turnover and retention rates are not symmetric. The turnover rate has a slightly longer tail on the right-hand side. On the other hand, the retention rate distribution has a long tail on the left side, and $25 \%$ of companies had $100 \%$ female retention rates. For this reason, we created a dummy variable for the retention rate by assigning the value of 1 to companies with $100 \%$ retention rate and 0 to others. 


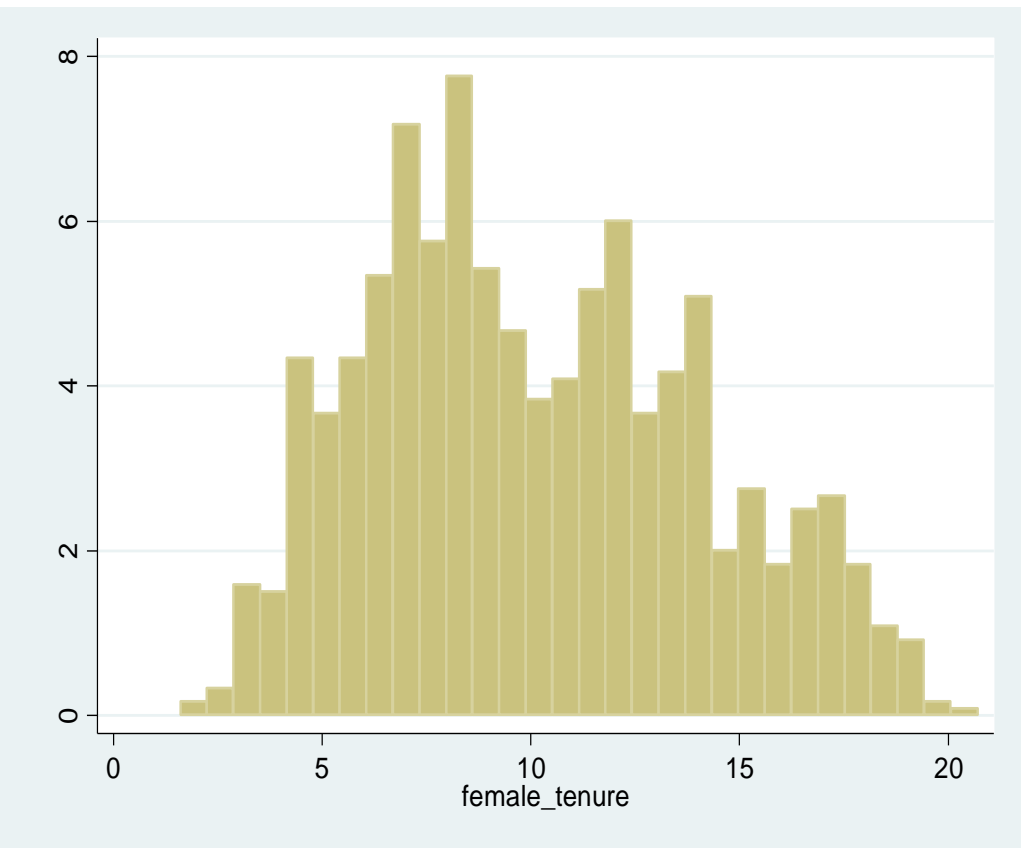

(a) Female tenure years

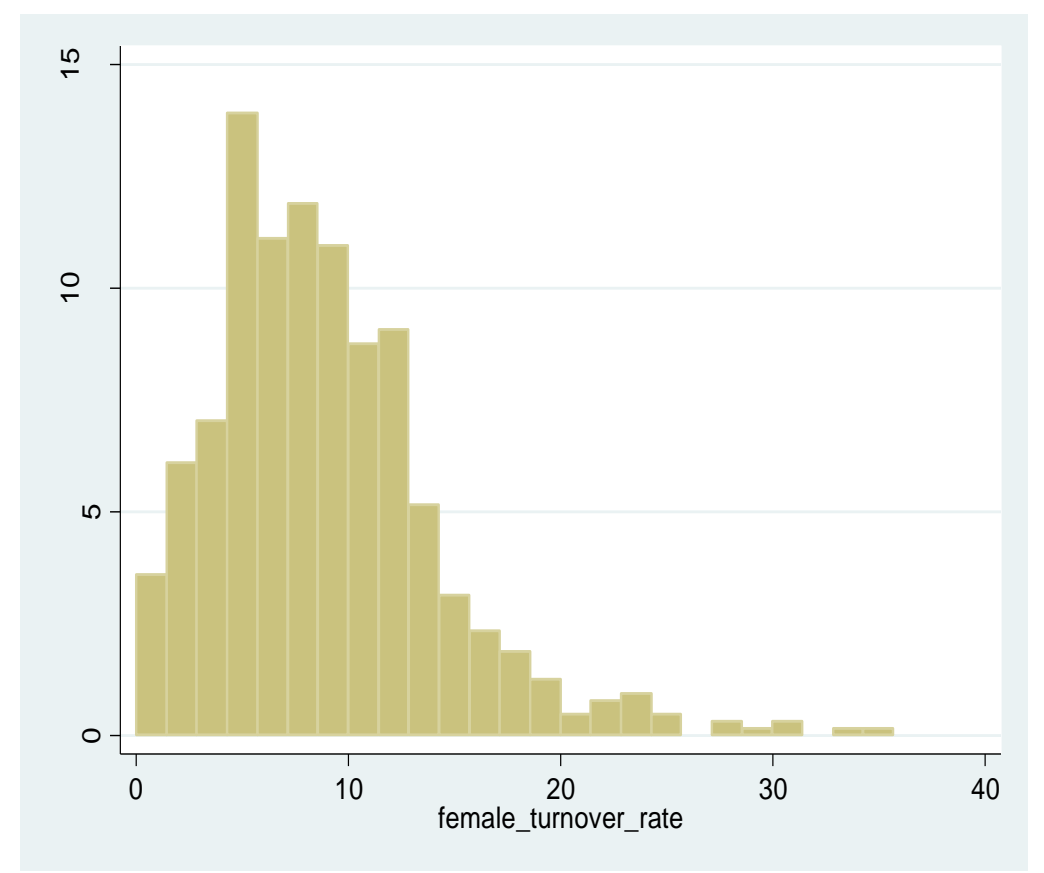

(b) Female turnover rate 


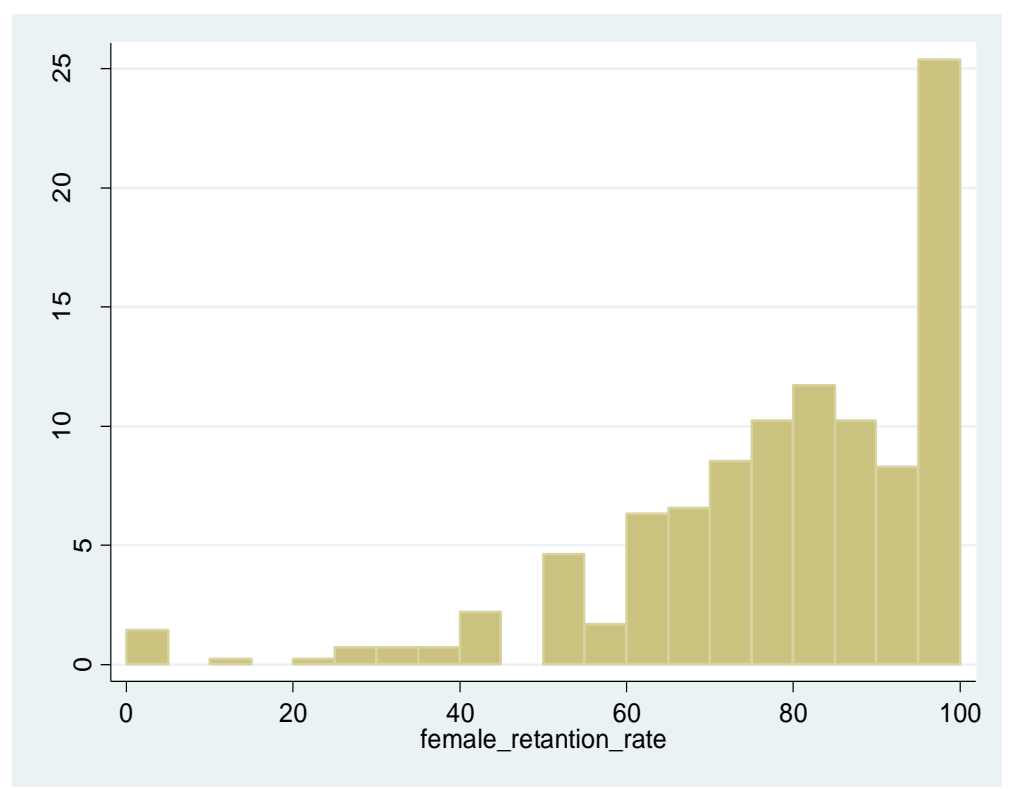

(c) Female new graduates' retention rate

Figure 1. Distribution of three dependent variables

\subsubsection{Explanatory Variables}

Organizational size and industry categories are controlled as $X_{i t}$ in our analysis. Organizational size is measured using the logarithm of the number of full-time male workers. Additionally, we create 15 industrial dummy variables based on the Japan Standard Industry Classification.

As various factors might affect the turnover intentions of female employees in a company, it was necessary to control for these influences to observe the relationship between WLB policies and job tenure or turnover rates for female employees. It might be expected that labor unions, monthly averages of overtime work hours, commuting allowances, qualification allowances, and initial salary influence the female turnover rate. Moreover, the proportion of married women and female managers in a company might influence the retention rate of female new graduates. Therefore, these variables have been used as control variables.

As previously mentioned, the Quarterly Female Employment Report in Japan provided information on the types of WLB policies available within a company. However, it is not apparent whether all employees were able to access these policies. Despite the lack of detailed information on the application of WLB practices, it seemed reasonable to assume that companies with these policies were more likely to balance employees' work and family lives than those without. As such, we created dummy variables $Z_{i t}$ for all WLB policies by defining companies with a specific WLB policy to take the value 1 , and others 0 .

As already noted, the adoption of some WLB policies is still low in most organizations in our sample. Therefore, analyzing the effect of these WLB policies, where they do exist, is significant. We use WLB policies such as maternity pay, childcare leave benefits, family-care leave system, family-care leave benefits, flextime system, and reemployment system in our analysis.

The Appendix shows the composition of the panel dataset from the Quarterly Female Employment Report, where each edition does not publish the same information about the WLB practice in the same company. The three dependent variables are not listed in all editions. The average job tenures for female employees are provided in the 2000 and 2003-2009 editions. Female turnover rates are provided in the 2004-2009 editions, and retention rates for female new graduates only in the 2005-2009 editions. Consequently, as shown by the Appendix table, our analyses and implications are limited. 


\section{Results}

\subsection{Cross-Sectional Analysis}

Table 3 reports the estimated effect of WLB policies on job tenure for female employees. First, our hypothesis is that firms WLB policies would increase the job tenure of female employees. We display only the results of the OLS regression for the 2000 survey edition. In Table 3, the coefficient of the family-care leave benefits has a negative effect on job tenure in estimation [1]. Contrary to our expectations, family-care leave benefit policies do not have a positive impact on job tenure for female employees. Family-care is an uncertain future problem for young family members, indicating these policies have not been fully appealing to female workers. However, maternity pay is statistically significant at the $1 \%$ level in estimation [1]. This indicates that the adoption of the maternity pay leave system is prospective for higher female tenure. The flextime system is also an important component of WLB policies. However, the results of the OLS estimation show that the flextime system is not associated with longer job tenure for female employees. The results also show that overtime work hours are negatively related to the job tenure of female employees, and the coefficient is significant at the $1 \%$ level in estimation [1].

Table 3. OLS (2000)

\begin{tabular}{|c|c|c|}
\hline & [1] & [2] \\
\hline Dependent Variable & Average Tenure of Female Employees & $\begin{array}{l}\text { Tenure Gap (Male and } \\
\text { Female) }\end{array}$ \\
\hline \multicolumn{3}{|l|}{ WLB Variables } \\
\hline \multirow[t]{2}{*}{ Maternity pay } & 2.473 & 0.804 \\
\hline & $(0.636)^{* * *}$ & $(0.655)$ \\
\hline \multirow[t]{2}{*}{ Childcare benefit } & 0.995 & 2.654 \\
\hline & $(1.126)$ & $(1.160)^{* *}$ \\
\hline \multirow[t]{2}{*}{ Family-care leave } & -0.407 & -1.393 \\
\hline & $(0.691)$ & $(0.712)^{*}$ \\
\hline \multirow[t]{2}{*}{ Family-care benefit } & -2.638 & -0.145 \\
\hline & $(1.030)^{* *}$ & $(1.061)$ \\
\hline \multirow[t]{2}{*}{ Flextime system } & 0.664 & 0.049 \\
\hline & $(0.669)$ & $(0.689)$ \\
\hline \multirow[t]{2}{*}{ Reemployment system } & 0.154 & 0.642 \\
\hline & $(0.574)$ & $(0.592)$ \\
\hline \multicolumn{3}{|l|}{ Control Variables } \\
\hline \multirow[t]{2}{*}{ Organization size } & 0.065 & 1.085 \\
\hline & $(0.293)^{* * *}$ & $(0.302)^{* * *}$ \\
\hline \multirow[t]{2}{*}{ Labor union } & 1.813 & -0.246 \\
\hline & $(0.988)^{*}$ & $(1.018)$ \\
\hline \multirow[t]{2}{*}{ Monthly average overtime work (hour) } & -0.071 & -0.557 \\
\hline & $(0.028) * * *$ & $(0.029)^{*}$ \\
\hline \multirow[t]{2}{*}{ Commuting allowance } & 1.136 & 0.562 \\
\hline & $(0.672)^{*}$ & $(0.692)$ \\
\hline Published by Sciedu Press & 147 & SN 1923-4007 E-ISSN 1923-4015 \\
\hline
\end{tabular}


Qualification allowance

Initial Salary $(\log )$

Constant

Observations

Note: $* * *, * *$, and * indicate significance at the $1 \%, 5 \%$, and $10 \%$ levels, respectively. Robust standard errors are shown between parentheses, and 11 industrial dummies are included in our analysis.

To explore the issue further, we recalculate the equations using the tenure gap between male and female employees, rather than female tenure alone. In estimation [2], with regard to WLB variables, the family-care leave coefficient is statistically significant, and narrows the gap in tenure between male and female employees. However, the childcare benefit is significant in widening the tenure gap. The ratio of the companies having this system is only $1 \%$, so we have to reexamine this result.

\subsection{Panel Data Analysis}

Next, we estimate the random effects model in Table 4, and report the effects of WLB policies on job tenure for female employees, turnover rates for female employees, and retention rates for female new graduates.

Table 4. Random effects model

\begin{tabular}{|c|c|c|c|}
\hline & [1] & [2] & [3] \\
\hline Dependent Variable & Average Tenure & Turnover Rate & $\begin{array}{c}\text { New Graduate Retention } \\
\text { Rate }\end{array}$ \\
\hline \multirow[t]{2}{*}{ Maternity leave } & -1.152 & 0.309 & \\
\hline & $(1.568)$ & $(0.659)$ & \\
\hline Maternity pay & $(0.269)$ & $(0.084)$ & $(0.238) * *$ \\
\hline \multirow[t]{2}{*}{ Childcare leave } & -0.239 & 0.081 & \\
\hline & $(0.671)$ & $(0.268)$ & \\
\hline Family-care leave & $(0.391)$ & $(0.087)^{* * *}$ & $(0.247)$ \\
\hline \multirow[t]{2}{*}{ Family-care benefit } & -0.285 & -0.686 & 0.431 \\
\hline & $(0.528)$ & $(0.271)^{* *}$ & $(0.988)$ \\
\hline \multirow[t]{2}{*}{ Flextime system } & 2.048 & -0.202 & 0.071 \\
\hline & $(0.471)$ & $(0.095)^{* *}$ & $(0.250)$ \\
\hline \multirow[t]{2}{*}{ Reemployment system } & -0.899 & 0.089 & -0.412 \\
\hline & $(0.351)$ & $(0.085)$ & $(0.259)$ \\
\hline
\end{tabular}




\section{Control Variables}

$\begin{array}{lccc}\text { Organization size } & -1.036 & -0.058 & -0.295 \\ & (0.155)^{* * *} & (0.048) & (0.158)^{*} \\ \text { Labor union } & 2.424 & -0.069 & 0.425 \\ & (0.494)^{* * *} & (0.104) & (0.309) \\ \text { Monthly average overtime work (hour) } & 0.001 & 0.001 & -0.001 \\ \text { Commuting allowance } & (0.010) & (0.001) & (0.011) \\ & 0.681 & 0.001 & 0.071 \\ \text { Qualification allowance } & (0.426) & (0.093) & (0.286) \\ & 0.275 & 0.118 & -0.035 \\ \text { Initial Salary (log) } & (0.363) & (0.081) & (0.232) \\ & 1.702 & -1.694 & 1.693 \\ \text { Proportion of female managers } & (1.707) & (0.656)^{* * *} & (1.755) \\ & & & -3.223 \\ \text { Proportion of married women } & & & (2.448) \\ \text { Constant } & & & 2.519 \\ & & & (0.845)^{* * *}\end{array}$

Note: $* * * * *$, and $*$ indicate significance at the $1 \%, 5 \%$, and $10 \%$ levels, respectively. Robust standard errors are shown between parentheses, and 11 industrial dummies are included in our analysis.

\subsubsection{Female Job Tenure}

The results are shown under estimation [1]. The coefficient of maternity pay is significant at the 5\% level in the random effects model. Therefore, in the random effects estimation, firms with a maternity pay system can increase the tenure of their female employees. According to organization size and the existence of labor unions, these variables are typically correlated. The positive effect of the labor union could cancel the negative effect of organization size.

\subsubsection{Female Turnover Rate}

The results are shown under estimation [2]. Regarding the turnover rate for female employees, the coefficient of maternity pay is not significant. However, the results in estimation [2] show that family-care leave, family-care benefits, and flextime system can decrease the turnover rate for female employees. In this estimate, the initial salary and the child care benefits are correlated, and the effect of the latter could negatively impact the turnover rate if the initial salary variable is not considered.

\subsubsection{Female Retention Rate}

We also estimate the random effects probit to test our hypothesis, according to which firms with WLB policies will have a higher retention rate for female new graduates. The estimation results are shown under estimation [3]. The coefficient of maternity pay is significant at the $5 \%$ level in the random effects model. Moreover, the population of married women is also significant at the $1 \%$ level in estimation [3]. Therefore, they might become role models in the workplace. 


\subsection{First-Differences Analysis}

To remove the unobserved firm effect, we difference all variables. Therefore, we regress the change in dependent variables on the change in all independent variables.

Table 5 shows the result of using OLS after the first difference. We focus on the coefficient of maternity pay change, which is statistically significant at the $10 \%$ level only in estimations [1] and [2]. This means that firms introducing a maternity pay system from 2003 to 2006 increased their female job tenure. On the other hand, the reemployment system decreases female job tenure. In other words, the companies with shorter female job tenures might adopt the reemployment system.

Table 5. First-differences model

Dependent variable: Average Tenure of Female Employee

\section{Period}

[1] 2000-2003 [2] 2000-2006

[3] 2000-2009

\section{WLB Variables}

Maternity leave

Maternity pay

2.071

2.932

1.812

$(1.170)^{*}$

$(1.344)^{*}$

Childcare leave

$-2.514$

$-2.88$

(1.789)

(2.135)

Childcare benefit

$-0.106$

$-0.821$

0.545

(0.672)

(1.142)

Family-care leave

$-0.964$

$-1.954$

$-3.144$

(0.955)

(2.007)

Family-care benefit

0.339

0.665

0.904

(0.593)

(1.219)

Flextime system

Reemployment system

$-0.772$

$-1.991$

$-4.555$

(0.754)

$(1.183)^{*}$

$(1.588)^{* * *}$

\section{Control Variables}

Organization size

$$
-1.758
$$

$-2.291$

$-4.019$

$(0.658) * * *$

$(0.552) * * *$

$(0.813)^{* * *}$

Labor union

Monthly average overtime work (hour)

$-0.318$

(0.041)

Commuting allowance
0.911

(1.171)
1.369

(2.043)
0.007

(0.047)

$-0.082$ 


\begin{tabular}{lccc} 
Qualification allowance & 0.115 & -0.261 & 4.023 \\
& $(0.985)$ & $(2.047)$ & $(3.703)$ \\
Initial Salary (log) & 7.431 & 16.846 & $(10.369)^{*}$ \\
& $(5.022)$ & $(10.902)$ & -168.667 \\
Proportion of female managers & & & $(128.158)$ \\
Proportion of married women & & -175.182 & 229 \\
Constant & -66.529 & $(133.218)$ & 0.386 \\
\hline Observations & $(60.958)$ & 288 & 0.372 \\
Adjusted R-squared & 351 & 0.142 & \\
\hline
\end{tabular}

Note: $* * *, * *$, and * indicate significance at the $1 \%, 5 \%$, and $10 \%$ levels, respectively. Robust standard errors are shown between parentheses, and 11 industrial dummies are included in our analysis.

\section{Conclusion}

This study explores the relationships between work-life balance (WLB) policies and three indicators concerning women's careers - job tenure, turnover rates, and new graduate retention rate. We tested these relationships using three types of estimations - cross-section, random-effect panel data, and first-differences analyses.

If institutional practices could help employees integrate work and life demands and, in turn, lower their voluntary turnover rates, an employer's investment in WLB practices would then be cost-justified.

Several findings in this study are noteworthy. First, in the cross-sectional estimate, the maternity pay system is a stronger predictor of female tenure. Organizational size and union dummy are also associated with significantly higher rates of female tenure (Table 3).

Second, family-care leave, family-care benefits, and flextime system have a negative effect on the turnover rate of female employees in the random effects model (Table 4). However, we found that maternity pay cannot explain female turnover rates. Even if maternity pay can be required during the maternity leave for female employees, if other work-life conflicts happen after the maternity leave and firms have not adopted appropriate WLB policies to solve these problems, female employees might to choose to quit the company.

Third, the maternity pay system had a positive effect on the job tenure for female employees and retention rate for female new graduates in the random effects models (Table 4). If the maternity leave or maternity pay systems can help women return to the workforce with the same employer, it is possible that, for female new graduates, the full amount of maternity pay is an attractive enough policy to enable women to stay with the same company if they plan to have children.

Our results mostly consist with those of Sakazume (2002), the most representative paper on this topic for Japan. However, different from prior studies, we showed how WLB policies contribute the retention rate for female new graduates in addition to the tenure years and the turnover rate for female employees. Furthermore, even after we control for time-constant unobserved heterogeneity, the maternity pay system has a positive effect in increasing female tenure (Table 5).

Finally, the main limitation of our research is that we could not clearly identify the ratio of the employees who are able to make use of these policies, meaning we could not directly and fully understand the most effective policies among the various WLB policies in our dataset. The main reason for this limitation is that the Quarterly Female Employment Report in Japan did not provide enough information on this topic. However, appropriate WLB policies will be integral to the creation of flexible workplaces conducive to the attraction, motivation, and retention of highly-valued employees. We suggest that the adoption of a wide range of WLB policies, addressing a variety of employee needs and demands, will have the potential to produce positive outcomes for the organization. 


\section{Acknowledgements}

This research is supported by Japan Society for the Promotion of Science (JSPS) Grant in Aid for Scientific Research (C) No.15K03516. I appreciate suggestions from Hisakazu Matushige and Hui-Yu Chiang at Osaka University.

\section{References}

Abe, M. (2008). The impact on firm performance. In H. Sato, \& E. Takeishi (Eds.), Human resource management and work-life balance (pp. 71-87). Keisoshobo Company.

Baker M., \& Milligan, K. (2008). How does job-protected maternity leave affect mothers' employment? Journal of Labor Economics, 26(4), 655-691. https://doi.org/10.1086/591955

Batt, R., \& Valcour, P. M. (2003). Human resources practices as predictors of work-family outcomes and employee turnover. Industrial Relations, 42(2), 189-220. https://doi.org/10.1111/1468-232X.00287

Cabinet Office, Government of Japan. (2013). Gender Equality White Paper, 2013 edition.

Cabinet Office, Government of Japan. (2017). Gender Equality White Paper, 2017 edition.

Chiang, H.-Y. (2012). The effect of work-life balance policies on female job tenure-an empirical study on Japanese firms. Asian Journal of Business and Management Sciences, 1(7), 25-37.

Dalton, D. R., \& Mesch, D. J. (1990). The impact of flexible scheduling on employee attendance and turnover. Administrative Science Quarterly, 35, 370-387. https://doi.org/10.2307/2393395

Eaton, S. C. (2003). If you can use them: Flexibility policies, organizational commitment, and perceived performance. Industrial Relations, 42(2), 145-167. https://doi.org/10.1111/1468-232X.00285

Greenwald, J. (1996). Balancing work \& family: kind hearts cold cash drive family benefits; employers find programs boost productivity, loyalty. Business Insurance, June 24.

Grover, S. L., \& Crooker, K. J. (1995). Who appreciates family-responsive human resource policies: The impact of family-friendly policies on the organizational attachment of parents and non-parents. Personnel Psychology, 48, 271-288. https://doi.org/10.1111/j.1744-6570.1995.tb01757.x

Imada, S., \& Ikeda, S. (2006). The effect of childcare leave policy and the issue of work-life balance). Japanese Journal of Labor Studies, 553.

Kawaguchi, A. (2002). Family-friendly policies and equal opportunity policies. The Japanese Journal of Labor Studies, 503, 15-28.

Kodama, N., Odaki, K., \& Takahashi, Y. (2005). Female employment and corporate performance. The Japanese Economic Studies, 52, 1-18.

Konrad, A., \& Mangel, R. (2000). The impact of work-life programs on firm productivity. Strategic Management Journal, 21, 1225-1237. https://doi.org/10.1002/1097-0266(200012)21:12<1225::AID-SMJ135>3.0.CO;2-3

Kossek, E. E., \& Nichol, V. (1992). The effects of on-site child care on employee attitudes and performance. Personnel Psychology, 45(3), 485-509. https://doi.org/10.1111/j.1744-6570.1992.tb00857.x

Matsubara, M., \& Wakisaka, A. (2005). Family-friendly policies in the United States and corporate performance (1): Survey on foreign materials concerning family-friendly policies and corporate performance. The Gakushuin University Journal of Economic Studies, 41(4).

Morita, Y., \& Kaneko, Y. (1998). The effects of the child care leave on women in the workforce. The Japanese Journal of Labor Studies, 459, 50-62.

Perry-Smith, J. E., \& Blum, T. C. (2000). Work-family human resource bundles and perceived organizational performance. Academy of Management Journal, 43(6), 1107-1117. https://doi.org/10.2307/1556339

Sakazume, H. (2002). Impacts of family-friendly practices on employee attitude and organizational performance. The Japanese Journal of Labor Studies, 503, 29-42.

Shigeno, Y. (2005). Corporate benefits from child-care support measures. The Economics of Osaka University, 54, 281-295.

Shigeno, Y., \& Ōkusa, Y. (1998). The effect of the child-care leave system on female marriage and constant career development. The Japanese Journal of Labor Studies, 459, 39-49.

Takeishi, E. (2006). The significance of work-life balance policies. The Japanese Journal of Labor Studies, 553. 
Toyo Keizai. (2000-2009). Quarterly Female Employment Report. Tokyo: Toyo Keizai.

Wakisaka, A. (2006). What are family-friendly organizations? The relationship with equal opportunity and firm performance. Journal of Household Economics, 71.

Youngblood, S. A., \& Chambers-Cook, K. (1984). Child care assistance can improve employee attitudes and behavior. The Personnel Administrator, 29(2), 45-50.

Appendix. Variables obtained from each publication (2000-2009)

\begin{tabular}{|c|c|c|c|c|c|c|c|c|c|c|}
\hline Variable & 2000 & 2001 & 2002 & 2003 & 2004 & 2005 & 2006 & 2007 & 2008 & 2009 \\
\hline Turnover Intention & - & - & - & - & - & - & - & - & - & - \\
\hline Female job tenure (year) & - & I & I & - & - & - & - & - & - & - \\
\hline Male job tenure & - & l & l & - & - & - & - & - & - & - \\
\hline Tenure gap (male and female) & - & l & l & - & - & - & - & - & - & - \\
\hline Women turnover rate & l & l & l & l & l & - & - & - & - & - \\
\hline Women retention rate & l & l & l & I & l & I & - & - & - & - \\
\hline \multicolumn{11}{|l|}{ WLB Policies (dummies) } \\
\hline Maternity leave & - & - & - & - & - & - & - & - & - & - \\
\hline Maternity pay & - & - & - & - & - & - & - & - & - & - \\
\hline Child-care leave & - & - & - & - & - & - & - & - & - & - \\
\hline Child-care benefit & - & - & - & 2002 & 2002 & 2002 & 2002 & 2002 & 2002 & 2002 \\
\hline Family-care leave & - & - & - & 2002 & 2002 & 2002 & 2002 & 2002 & 2002 & 2002 \\
\hline Family-care benefit & - & - & - & 2002 & 2002 & 2002 & 2002 & 2002 & 2002 & 2002 \\
\hline Flextime system & - & 2000 & 2000 & 2000 & 2000 & 2000 & 2000 & 2000 & 2000 & 2000 \\
\hline Reemployment system & 2001 & - & - & 2002 & 2002 & 2002 & 2002 & 2002 & 2002 & 2002 \\
\hline \multicolumn{11}{|l|}{ Organization Size } \\
\hline Number of male employees $(\log )$ & - & 2000 & 2003 & - & - & - & - & - & - & - \\
\hline \multicolumn{11}{|l|}{ Other Characteristics } \\
\hline Labor union dummy & - & - & - & 2002 & 2002 & 2002 & 2002 & 2002 & 2002 & 2002 \\
\hline $\begin{array}{l}\text { Monthly average overtime work } \\
\text { (hour) }\end{array}$ & 2003 & 2003 & 2003 & - & - & - & - & - & - & - \\
\hline Commuting allowance dummy & 2001 & - & - & 2002 & 2002 & 2002 & 2002 & 2002 & 2002 & 2002 \\
\hline Qualification allowance dummy & 2001 & - & - & 2002 & 2002 & 2002 & 2002 & 2002 & 2002 & 2002 \\
\hline Initial salary $(\log )$ & 2001 & - & - & - & - & - & - & - & - & - \\
\hline Proportion of married women & - & - & - & - & - & - & - & - & - & - \\
\hline $\begin{array}{l}\text { Proportion of female in managerial } \\
\text { posts }\end{array}$ & - & - & - & - & - & - & - & - & - & - \\
\hline
\end{tabular}

